\title{
PENGARUH STRATEGI MEKANISME KOPING TERHADAP TINGKAT KECEMASAN PADA IBU PRIMIGRAVIDA DI RUMAH SAKIT UMUM DI MEDAN TAHUN 2019
}

\author{
Rostinah Manurung \\ Program Studi S1 Keperawatan, Universitas Imelda Medan, Indonesia \\ Email : rostinahmanurung@gmail.com
}

\begin{abstract}
ABSTRAK
Kehamilan pertama bagi seorang ibu primigravida merupakan salah satu periode krisis dalam kehidupannya. Kecemasan tersebut dapat muncul pada ibu hamil karena masa panjang saat menanti kelahiran dan bayangan tentang hal-hal yang menakutkan saat proses persalinan walaupun belum tentu terjadi. Situasi ini menimbulkan perubahan drastis, bukan hanya fisik tetapi juga psikologis. Untuk menghadapi kecemasan tersebut dibutuhkan mekanisme koping yang baik, dalam menurunkan kekhawatiran atau kecemasan tersebut. Semakin adaptif mekanisme koping ibu hamil maka tingkat gangguan psikologis semakin rendah, namun jika mekanisme penderita maladaptive maka tingkat gangguan psikologisnya semakin berat. Penelitian ini bertujuan untuk mendeskripsikan adanya pengaruh strategi mekanisme koping terhadap tingkat kecemasan pada ibu Primigravida. Penelitian dilakukan pada bulan April tahun 2019 di Rumah Sakit Umum di Medan. Jenis penelitian yang digunakan adalah pre experimental design dengan pendekatan one - shoot case study. Populasi dalam penelitian ini adalah 80 orang. Tehnik sampling pada penelitian ini adalah purposive sampling dengan demikian jumlah sampel 30 orang. Analisis statistik yang digunakan uji chi square. Hasil analisis bivariat menunjukkan bahwa strategi mekanisme koping terhadap tingkat kecemasan pada ibu primigravida didapatkan nilai $p$ sebesar 0,000 nilai $p=0,000<0,05$ dapat diartikan bahwa HA diterima ada pengaruh antara strategi mekanisme koping dengan tingkat kecemasan pada ibu primigravida di Rumah Sakit Umum di Medan tahun 2019. Ada pengaruh strategi mekanisme koping terhadap tingkat kecemasan pada ibu primigravida di rumah sakit umum di medan tahun 2019, diharapkan ibu hamil dapat mengatur kopingnya dengan baik agar mengurangi tingkat kecemasan pada ibu hamil.
\end{abstract}

Kata kunci : Ibu primigravida,Strategi mekanisme koping dan tingkat kecemasan.

ABSTRACT

The first pregnancy for a primigravid mother is one of the crisis periods in her life. Anxiety can arise in pregnant women because of the long period while waiting for birth and shadows about things that are frightening during childbirth, although not necessarily happen. This situation caused a drastic change, not only physical but also psychological. To deal with these anxiety needed a good coping mechanism, in reducing these worries or anxieties. The more adaptive the coping mechanism of pregnant women the lower the level of psychological disorders, but if the mechanism of the sufferer is maladaptive, the level of psychological disorders will be more severe. This study aims to describe the influence of coping mechanism strategies on anxiety levels in Primigravida mothers. The study was conducted in April 2019 at Hospital Medan. The type of research used was a pre-experimental design with a one-shoot case study approach. The population in this study was 80 people. The sampling technique in this study was purposive sampling with a total sample of 30 people. Statistical analysis used the chi square test. The results of the bivariate analysis showed that the coping mechanism strategy on anxiety levels in primigravida mothers obtained $p$ value of 0,000 $p$ value $=0,000<0.05$ can be interpreted that HA was accepted to have an influence between coping mechanism strategies with anxiety levels in primigravida mothers at General Hospital in Medan in 2019. There is an influence of coping mechanism strategies on the level of anxiety in primigravida mothers in the general hospital in Medan in 2019, it is expected that pregnant women can manage their coping well in order to reduce the level of anxiety in pregnant women.

Keywords: Anxiety levels, Mechanism strategies and Primigravida mothers, Coping.

\section{PENDAHULUAN}

Kehamilan pertama bagi seorang ibu primigravida merupakan salah satu periode krisis dalam kehidupannya. Kecemasan tersebut dapat muncul karena masa panjang saat menanti kelahiran, dan bayangan tentang hal-hal yang menakutkan saat proses persalinan walaupun belum tentu terjadi. 
Situasi ini menimbulkan perubahan drastis, bukan hanya fisik tetapi juga psikologis (Walangadi, N.N. Dkk, 2014). Pada umumnya seorang ibu yang pertama kali hamil akan senang dengan kehamilannya. Begitu besar rasa ingin tahu mereka terhadap perubahan diri dan perkembangan janin. Tapi disaat yang sama, tumbuh kecemasan dalam diri calon ibu tersebut. Bahkan bagi ibu yang hamil kedua, ketiga dan seterusnya (Shodiqoh, R.R. \& Syahrul, F. 2014).

Kematian dan kesakitan pada ibu hamil dan bersalin serta bayi baru lahir sejak lama telah menjadi masalah, khusunya di negaranegara berkembang. Sekitar 25-50\% kematian perempuan usia subur disebabkan oleh hal yang berkaitan dengan kehamilan dan persalinan. Kematian saat melahirkan menjadi penyebab utama mortalitas perempuan pada masa puncak produktifitasnya World Health Organization (WHO) memperkirakan setiap tahun terjadi 210 juta kehamilan diseluruh dunia. Dari jumlah ini 20 juta perempuan mengalami kesakitan sebagai akibat kehamilan. Sekitar 8 juta mengalami komplikasi yang mengancam jiwa, dan lebih dari 500.000 meninggal. Sebanyak 210.000 dari jumlah ini hampir $50 \%$ terjadi di negara-negara Asia Selatan dan Tenggara, termasuk Indonesia (Shodiqoh, R.R. \& Syahrul, F. 2014).

Berdasarkan Survey Kesehatan dan Demografi Indonesia (SKDI) jumlah kasus kematian bayi turun dari 33.278 di tahun 2015 menjadi 32.007 pada tahun 2016, dan di tahun 2017 di semester I sebanyak 10.294 kasus. Demikian pula dengan angka kematian Ibu turun dari 4.999 tahun 2015 menjadi 4912 di tahun 2016 dan di tahun 2017 (semester I) sebanyak 1712 kasus. Tingginya angka kematian maternal disebabkan oleh: (1) Rendahnya pengetahuan mengenai sebabsebab dan penanggulangan komplikasikomplikasi penting selama hamil, persalinan dan nifas, (2) Rendahnya pengetahuan tentang kesehatan reproduksi, (3) Pelayanan kebidanan yang baik belum mencakup semua wilayah.

Dalam jurnal (handayani, R. 2015) di Indonesia terdapat 373.000 .000 orang ibu hamil yang mengalami kecemasan dalam menghadapi persalinan ada sebanyak 107.000.000 orang $(28,7 \%)$. Sedangkan seluruh populasi di pulau Sumatra terdapat
679.765 ibu hamil yang mengalami kecemasan dalam menghadapi persalinan 355.873 orang $(52,3 \%)$. Kecemasan pada saat kehamilan dapat menyebabkan BBLR, dari hasil Riskesdas tahun 2013 menyatakan bahwa persentase balita 0-59 bulan sebesar $10,2 \%$. Sementara di Jawa Tengah persentase BBLR pada bayi 0-59 bulan mencapai $10 \%$. Dalam hal itu, kecemasan memang tidak berdampak langsung, namun dengan kecemasan akan meningkatkan kehamilan beresiko hingga komplikasi kehamilan sehingga dapat menyebabkan hal tersebut.

Hasil survei awal pada tanggal 21 maret 2019 di Rumah Sakit Umum di Medan didapatkan data ibu hamil dari 3 bulan terakhir sebanyak 250 orang. Hasil wawancara kepada sebagian ibu hamil, menunjukkan 3 dari 7 pasien mengatakan merasa cemas dan khawatir tentang keadaan yang dialaminya mekanisme koping yang dilakukan oleh pasien juga belum begitu optimal sehingga pasien merasa cemas akan kehamilannya. Berdasarkan latar belakang yang di atas maka saya tertarik untuk meneliti pengaruh Strategi Mekanisme Koping Terhadap Tingkat Kecemasan Pada Ibu Primigravida di Rumah Sakit Umum di Medan Tahun 2019.

\section{METODE PENELITIAN}

Jenis penelitian yang digunakan adalah pre experimental design. Sedangkan desain penelitian menggunakan one - shoot case study (study kasus satu tembakan) terdapat sampel diberi treatment (perlakuan) dan selanjutnya diobservasi hasilnya. Dalam eksperimen ini subjek disajikan dengan beberapa jenis perlakuan lalu diukur hasilnya. Metode penelitian ini bertujuan untuk mengetahui pengaruh strategi mekanisme koping dengan tingkat kecemasan pada ibu primigravida.

$\mathrm{X}$ Y

Keterangan :

$\mathrm{X}=$ Mekanisme koping

$\mathrm{Y}=$ Kecemasan

- $=$ Pengaruh

Lokasi penelitian dilakukan di RSU di Medan. Penelitian ini dimulai pada bulan Februari 2019 sampai dengan Mei 2019, dimulai dari proses pengajuan judul sampai akan dilakukannya penelitian, direncanakan 
proses pengumpulan data akan dilaksanakan pada bulan Maret 2019. Populasi adalah keseluruhan subjek penelitian. Populasi dalam penelitian ini adalah seluruh ibu hamil di RSU di Medan dengan rata-rata pasien setiap bulan sebanyak 80 orang. Teknik pengambilan sampel yang digunakan adalah dengan purposive sampling, yakni pengambilan sampel yang dilakukan dengan penentuan kriteria oleh peneliti. Adapun kriteria pengambilan sampel dalam penelitian ini antara lain :

1. Ibu primigravida yang ada di Rumah Sakit Umum di Medan.

2. Usia ibu primigravida 20 sampai 40 tahun, untuk melihat efek dari usia produktif terhadap kecemasan dan koping individu.

3. Bersedia menjadi responden.

Besarnya sampel dalam penelitian ini ditemukan dengan cara rumus slovin sebagai berikut:

$$
\begin{aligned}
\mathrm{n} & =\mathrm{N} / 1+\left(\mathrm{N} \mathrm{x} \mathrm{e}^{2}\right) \\
& =80 / 1+\left(83 \times(0,14)^{2}\right) \\
& =80 / 2,6 \\
& =30 \text { responden }
\end{aligned}
$$

\section{Defenisi Operasional Dan Pengukuran Defenisi Operasional}

Defenisi operasional adalah tentang batas variabel yang dimaksud, atau tentang apa yang diukur oleh variabel yang bersangkutan. Berdasakan uraian diatas maka defenisi operasional yang didapat penulis dari variabel yang akan diteliti adalah:

Tabel 1. Defenisi Operasional Dan Pengukuran

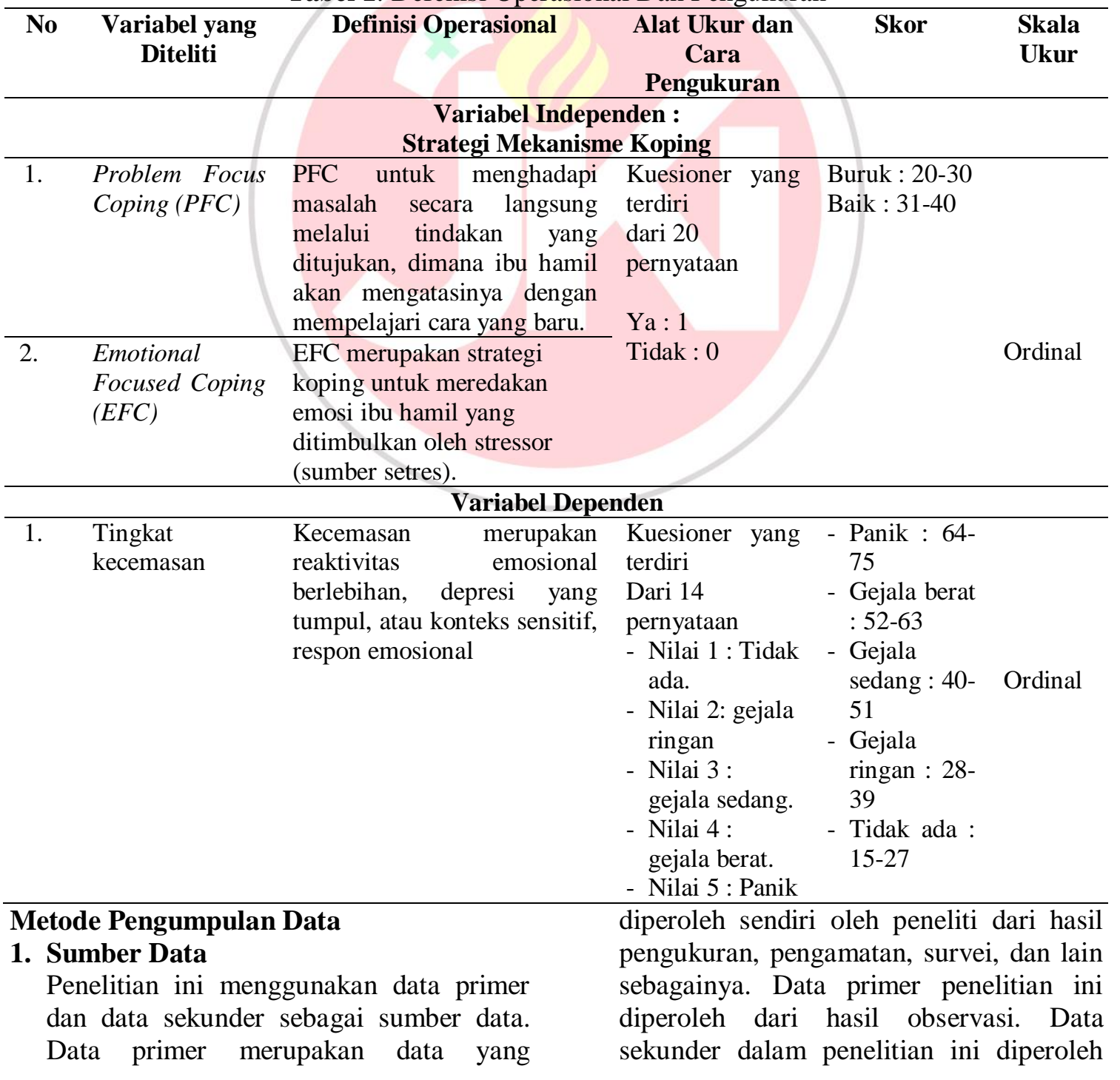


dari bagian rekam medik, yaitu jumlah ibu hamil dan data lengkap ibu hamil yang primigravida yang berisi nama, usia, jenis kelamin, dan alamat pasien.

\section{Tehnik Pengumpulan Data}

Responden pada penelitian ini yaitu ibu primigravida. Setelah mendapat responden, selanjutnya dijelaskan pada responden tentang tujuan, manfaat penelitian.

\section{Analisa Data}

\section{Analisa Univariat}

Analisis data univariat bertujuan untuk mendeskripsikan karakteristik responden dan karakteristik masing-masing variabel yang diteliti. Variabel yang berbentuk kategori (jenis kelamin dan pendidikan) disajikan dalam bentuk proporsi, sedangkan variabel yang berbentuk numerik (usia) disajikan berupa nilai dalam bentuk mean, median, standar deviasi, dan nilai minimum-maksimum.

\section{Analisa Bivariat}

Analisis data bivariat bertujuan untuk menganalisis kelompok data yang terdiri dari variabel independen dan dependen. Kelompok data yang akan dianalisis yaitu variabel strategi mekanisme koping sebagai variabel independen dan variabel tingkat kecemasan sebagai variabel dependen. Skala data pada penelitian ini adalah ordinal untuk variabel dependen. Teknik analisis data yang digunakan pada penelitian ini sebagai berikut: Perbedaan tingkat kecemasan pada ibu primigravida sebelum pemberian strategi mekanisme koping, digunakan analisis Chi-square dengan Ha diterima jika $\mathrm{p}<0,05$.

\section{HASIL DAN PEMBAHASAN}

\subsection{Hasil}

\section{Hasil Univariat}

Setelah dilakukannya penelitian dengan judul "Pengaruh strategi mekanisme koping terhadap tingkat kecemasan pada ibu primigravida di Rumah Sakit Umum Imelda Pekerja Indonesia Medan tahun 2019" terhadap 30 responden yang diambil dengan cara purposive sampling maka diperoleh hasil sebagai berikut :

\section{Data Demografi}

Tabel 2. Distribusi Karakteristik Responden Berdasarkan umur Tentang Pengaruh strategi mekanisme koping terhadap tingkat kecemasan pada ibu primigravida di Rumah Sakit Umum di Medan tahun 2019

\begin{tabular}{cccc}
\hline No & Karakteristik & F & \% \\
\hline 1 & $20-25$ & 7 & 23,3 \\
\hline 2 & $26-30$ & 19 & 63,3 \\
\hline 3 & $31-35$ & 4 & 13,3 \\
\hline 4 & $36-40$ & 0 & 0 \\
\hline & Jumlah & $\mathbf{3 0}$ & $\mathbf{1 0 0}$ \\
\hline
\end{tabular}

Berdasarkan tabel 2 diatas terlihat bahwa mayoritas responden yang interval usianya 26-30 tahun sebanyak 19 orang $(63,3 \%)$, sedangkan minioritas responden yang interval usianya 31-35 tahun sebanyak 4 orang $(13,3 \%)$

Tabel 3. Distribusi Karakteristik Responden Berdasarkan Agama Tentang Pengaruh strategi mekanisme koping terhadap tingkat kecemasan pada ibu primigravida di Rumah

Sakit Umum di Medan tahun 2019

\begin{tabular}{cccc}
\hline No & Karakteristik & F & \% \\
\hline 1 & Islam & 19 & 63,3 \\
\hline 2 & Kristen katolik & 6 & 20 \\
\hline 3 & Kristen protestan & 5 & 16,7 \\
\hline 4 & Budha & 0 & 0 \\
\hline 5 & Hindu & 0 & 0 \\
\hline & Jumlah & $\mathbf{3 0}$ & $\mathbf{1 0 0}$
\end{tabular}

Berdasarkan table 3 diatas terlihat bahwa mayoritas responden berdasarkan agama islam sebanyak 19 orang $(63,3 \%)$, sedangkan minioritas responden berdasarkan agama Kristen protestan sebanyak 5 orang $(16,7 \%)$.

Tabel 4. Distribusi Karakteristik Responden Berdasarkan Pendidikan Tentang Pengaruh strategi mekanisme koping terhadap tingkat kecemasan pada ibu primigravida di Rumah

Sakit Umum di Medan tahun 2019

\begin{tabular}{cccc}
\hline No & Karakteristik & F & \% \\
\hline 1 & Tidak sekolah & 1 & 3,3 \\
\hline 2 & SD & 0 & 0 \\
\hline 3 & SMP & 5 & 16,7 \\
\hline 4 & SMA & 12 & 40 \\
\hline 5 & Perguruan Tinggi & 12 & 40 \\
\hline & & $\mathbf{3 0}$ & $\mathbf{1 0 0}$
\end{tabular}

Berdasarkan tabel 4 diatas dapat dilihat bahwa bahwa mayoritas responden berdasarkan pendidikan SMA dan Perguruan Tinggi sebanyak 12 orang (40\%) sedangkan minoritas responden berdasarkan pendidikan tidak sekolah sebanyak $1(3,3 \%)$. 


\section{Data Khusus}

Berdasarkan penelitian yang dilakukan pada tanggal 20 April 2019 di Rumah Sakit Umum di Medan diperoleh data khusus sebagai berikut :

1. Penerapan Strategi Mekanisme Koping

Tabel 5. Strategi Mekanisme Koping ibu Primigravida Sesudah Diterapkan di Rumah

Sakit Umum di Medan Tahun 2019

\begin{tabular}{cccc}
\hline No & Karakteristik & F & \% \\
\hline 1 & Buruk & 11 & 36,7 \\
\hline 2 & Baik & 19 & 63,3 \\
\hline & Jumlah & $\mathbf{3 0}$ & $\mathbf{1 0 0}$ \\
\hline
\end{tabular}

Berdasarkan table 5 diatas menunjukan bahwa strategi mekanisme koping pada ibu primigravida bersifat baik sebanyak 19 responden $(63,3 \%)$ sedangkan strategi mekanisme koping buruk sebanyak $(36,7 \%)$.

\section{Karakteristik Responden Berdasarkan} Tingkat Kecemasan pada Ibu Primigravida

Tabel 6. Distribusi Frekuensi berdasarkan Tingkat Kecemasan ibu Primigravida Sesudah Diterapkan di Rumah Sakit Umum di Medan Tahun 2019

\begin{tabular}{cccc}
\hline No & Karakteristik & F & \% \\
\hline 1 & Panik & 0 & 0 \\
\hline 2 & Gejala berat & 0 & 0 \\
\hline 3 & Gejala sedang & 5 & 16,7 \\
\hline 4 & Gejala ringan & 7 & 23,3 \\
\hline 5 & Tidak ada gejala & 18 & 60 \\
\hline & Jumlah & $\mathbf{3 0}$ & $\mathbf{1 0 0}$
\end{tabular}

Berdasarkan tabel 6 diatas menunjukan bahwa mayoritas tingkat kecemasan pada ibu primigravida bersifat tidak ada kecemasan sebanyak 18 responden (60\%) sedangkan minoritas untuk gejala sedang sebanyak $(16,7 \%)$

\section{Hasil Bivariat}

Pada penelitian ini data yang diperoleh dapat dianalisis bivariat yaitu untuk mengetahui pengaruh strategi mekanisme koping terhadap tingkat kecemasan pada ibu Primigravida di rumah sakit umum Imelda pekerja Indonesia medan tahun 2019.

Pengaruh Strategi Mekanisme Koping Terhadap Tingkat Kecemasan Pada Ibu Primigravida

Berdasarkan penelitian strategi mekanisme koping terhadap tingkat kecemasan pada ibu primigravida dapat dilihat pada tabel Wilcoxcon dibawah ini:

Tabel 7. Pengaruh Strategi Mekanisme Koping Terhadap Tingkat Kecemasan Pada Ibu Primigravida

\begin{tabular}{|c|c|c|c|c|c|c|}
\hline \multirow[t]{2}{*}{ No } & \multirow{2}{*}{$\begin{array}{c}\text { Mekanisme } \\
\text { koping }\end{array}$} & \multicolumn{3}{|c|}{ Tingkat Kecemasan } & \multirow[t]{2}{*}{ Total } & \multirow[t]{2}{*}{ P. Value } \\
\hline & & Gejala sedang & Gejala ringan & Tidak Ada & & \\
\hline 1 & Buruk & 4 & 2 & 5 & 11 & 0,000 \\
\hline 2 & Baik & 1 & 5 & 13 & 19 & \\
\hline & Total & 5 & 7 & 18 & 30 & \\
\hline
\end{tabular}

Berdasarkan tabel diatas strategi tahun 2019 adalah kategori baik 19 orang

mekanisme koping terhadap tingkat kecemasan pada ibu primigravida didapatkan nilai $\mathrm{p}$ sebesar 0,000 nilai $p=0,000<0,05$ dapat diartikan bahwa HA diterima ada pengaruh antara strategi mekanisme koping terhadap tingkat kecemasan pada ibu primigravida di Rumah Sakit Umum di Medan tahun 2019.

\subsection{Pembahasan}

Strategi Mekanisme Koping Pada Ibu Primigravida Di Rumah Sakit Umum Imelda Pekerja Indonesia Medan Tahun 2019

Hasil penelitian ini diperoleh mayoritas strategi mekanisme koping pada ibu primigravida di rumah sakit umum di medan $(63,3 \%)$, sedangkan strategi mekanisme koping buruk sebanyak $(36,7 \%)$ hal ini terlihat dari hasil penyebaran kuesioner yang telah diberikan, bahwa responden menyatakan koping individu baik, dimana usaha-usaha dalam mengatasi masalah yang dialami bisa diatasi dengan optimal.

Menurut asumsi peneliti, mekanisme koping pada ibu hamil tersebut kategori baik, dikarenakan berbagai masalah yang dihadapai oleh responden dapat diselesaikan dengan baik sehingga pasien tersebut mampu menjalani peroses kehamilan sampai menunggu proses melahirkan, responden tidak terbebani dan mampu mencari solusi dengan keadaanya, sehingga upaya maupun 
usaha dalam melakukan koping semakin baik.

Strategi mekanisme koping pada ibu hamil merupakan mekanisme yang digunakan individu dalam menghadapi perubahan yang diterima oleh ibu dapat bersifat adaptif dan maladaptive. Semakin adaptif strategi mekanisme koping pada ibu hamil maka tingkat gangguan psikologis semakin rendah, namun jika mekanisme koping penderita maladaptiv maka gangguan psikologisnya semakin berat. Seorang dapat mengatasi stress dan kecemasan dengan menggerakan sumber koping di lingkungan yang berupa modal ekonomi, kemampuan penyelesaian masalah, dengan sosial dan keyakinan budaya.

Sumber koping yang di manfaatkan dengan baik dapat membantu ibu hamil mengembangkan mekanisme koping yang adaptif, sehingga ibu hamil dapat menanggulangi kecemasan ditandai dengan tidak ada tingkat kecemasan yang berat dan panik. Hal ini terlihat pada hasil penelitian yaitu penggunaan sumber koping seperti dukungan sosial, asset materi dan nilai keyakinan individu yang membantu individu mengembangkan koping yang adaptif sehingga kecemasan yang dirasakan oleh individu tidak ada.

Penelitian ini juga sejalan dengan Hasil peneitian yang menunjukkan sebagian besar responden mempunyai strategi koping positif yaitu sebanyak 20 responden (66.67\%), sebagian besar responden mempunyai tingkat kecemasan ringan yaitu sebanyak 20 responden $(66.67 \%)$. Dan didapatkan hampir setengah responden yang mempunyai strategi koping positif dengan tingkat kecemasan ringan yaitu 12 respoden (40\%). Hasil penelitian menunjukkan $0.000<0.05$ berarti ada hubungan yang signifikan antara strategi coping dengan tingkat kecemasan pada ibu bersalin primigravida di VK bersalin (PONEK) RSUD JOMBANG.

\section{Tingkat Kecemasan Pada Ibu Primigravida Di Rumah Sakit Umum Di Medan Tahun 2019}

Hasil penelitian menunjukan mayoritas tingkat kecemasan pada ibu primigravida di rumah sakit umum di medan tahun 2019 adalah kategori kecemasan ringan sebanyak 7 orang $(23,3 \%)$, gejala sedang 5 orang
$(16,7 \%)$ sedangkan tidak ada kecemasan pada ibu primigravida 18 orang $(60 \%)$ hal ini terlihat dari hasil kuesioner yang diberikan, bahwa responden mengalmi berbagai kecemasan dan kekhawatiran terhadap kehamilan yang dialaminya.

Kecemasan adalah hal yang normal di dalam kehidupan karena kecemasan sangat dibutuhkan sebagai pertanda akan bahaya yang mengancam. Namun ketika kecemasan terjadi terus-menerus, tidak rasional dan intensitasnya meningkat, maka kecemasan dapat mengganggu aktivitas sehari-hari dan disebut sebagai gangguan kecemasan.

\section{Pengaruh Strategi Mekanisme Koping Terhadap Tingkat Kecemasan Pada Ibu Primigravida di Rumah Sakit Umum di Medan Tahun 2019}

Hasil penelitian menunjukkan bahwa, mayoritas atau cenderung mekanisme koping yang baik akan memberikan kontribusi yang baik pula pada tingkat kecemasan pasien, data menunjukkan 19 orang $(63,3 \%)$ sedangkan strategi mekanisme koping buruk sebanyak $(36,7 \%)$ dapat diartikan bahwa mekanisme koping yang baik maka tidak ada tingkat kecemasan pada ibu hamil karena ibu hamil dapat mengatasi masalah koping dengan baik masalah tentang kehamilannya serta hambatan yang ibu rasakan saat hamil dan upaya dukungan keluarga menjadi faktor pengurangan tingkat kecemasan pada ibu hamil tersebut .

Berdasarkan tabel diatas Hasil uji statistik Wilcoxon menunjukan dari 30 responden didapatkan nilai signifikansi (nilai p) sebesar 0,000 nilai $p=0,000<0,05$ dapat diartikan bahwa HA diterima ada pengaruh antara strategi mekanisme koping dengan tingkat kecemasan pada ibu primigravida di Rumah Sakit Umum di Medan tahun 2019.

\section{KESIMPULAN}

Berdasarkan hasil penelitian dan pembahasan yang dilakukan tentang pengaruh strategi mekanisme koping terhadap tingkat kecemasan pada ibu primigravida di rumah sakit umum di medan tahun 2019 menunjukkan bahwa strategi mekanisme koping pada ibu primigravida di rumah sakit umum di Medan tahun 2019 mayoritas adalah mekanisme koping yang baik sebanyak 19 responden $(63,3 \%)$ 
sedangkan strategi mekanisme koping buruk sebanyak $(36,7 \%)$. Untuk tingkat kecemasan pada ibu primigravida di Rumah Sakit Umum di Medan tahun 2019 mayoritas tidak ada kecemasan pada ibu primigravida bersifat tidak ada kecemasan sebanyak 18 responden (60\%) sedangkan minoritas untuk gejala sedang sebanyak (16,7\%). Hasil uji statistik Wilcoxon terdapat pengaruh strategi mekanisme koping terhadap tingkat kecemasan pada ibu primigravida di Rumah Sakit Umum di Medan tahun 2019 dengan nilai sig. sebesar $0,000 \quad(<0,05)$ sehingga dapat disimpulkan bahwa Ada pengaruh strategi mekanisme koping terhadap tingkat kecemasan pada ibu primigravida di Rumah Sakit Umum di Medan tahun 2019.

\section{REFERENCES}

Ahyar. (2010). Konsep Diri Dan Mekanisme Koping Dalam Aplikasi Keperawatan. Jakarta : EGC. 19 Maret 2019.

Alimul Hidayat A.A., (2010). Metode Penelitian Kesehatan Paradigma Kuantitatif. Jakarta: Heath Books. 19 Maret 2019.

Anissa, Ifdil. (2016). Konsep Kecemasan (Anxiety) Pada Lanjut Usia. Artikel Ilmiah : Universitas Negri Padang. 19 Maret 2019.

Asmadi. (2012). Teknik Prosedural Keperawatan: Konsep Dan Aplikasi Kebutuhan Dasar Klien. Jakarta: Salemba medika. 19 Maret 2019.

Astuti, H. (2012). Buku ajar asuhan kebidanan ibu 1. Jogjakarta: Rohima Press

Cheung, H.S., \& Sim, T.N. (2014). Social Support from Parents and Friends for Chinese Adolescents in Singapore. Youth and Society. 1-7

Danish, Nargis. (2010). Assessment of Pregnancy Outcome in Primigravida: Comparison Between Booked and Unbooked Patients. dari http://www.ayubmed.edu.pk/JAMC/PAS T/22-2/Nargis.pdf._19 Maret 2019.

Hani, ummi. dkk. 2011. Asuhan kebidanan pada kehamilan fisiologis. Jakarta: Salemba medika. 19 Maret 2019.

Janiwarty, B dan Pieter, H. Z. (2013). Pendidikan Psikologi untuk Bidan Suatu Teori dan Terapannya, Yogyakarta:
Rapha Publishing. Pada tanggal 10 Maret 2019.

Kaplan H.I, Sadock B.J, Grebb J.A. 2010. Sinopsis Psikiatri Jilid 2. Terjemahan Widjaja Kusuma. Jakarta: Binarupa Aksara. p. 17-35. 19 Maret 2019.

Kuswanti, Ina.S. Si. T, M. Kes. 2014. Asuhan Kehamilan. Yogyakarta : PT. Pustaka Pelajar. 19 Maret 2019.

Lipowski, A. dan Lipowska, D., 2011. Roulette-Wheel Selection Via Stochastic Acceptance. United States: Elsevier. 19 Maret 2019.

Manuaba, Ida A.C. (2013). Ilmu Kebidanan, Pennyakit Kandungan, dan KB Untuk Pendidikan Bidan Edisi 2. Jakarta: EGC. 19 Maret 2019.

Manuaba, Ida A.C. 2012. Buku Ajar Patologi Obstetri Untuk Mahasiswa Kebidanan. Jakarta : EGC. 19 Maret 2019.

Nursalam. 2013. Metodologi Penelitian Ilmu Keperawatan: Pendekatan Praktis. Jakarta: Salemba Medika. 19 Maret 2019.

Notoadmojo. (2012). Metodologi Penelitian Kesehatan. Jakarta: Rineka Cipta. 19 Maret 2019.

Prawirohardjo, S. 2009. Ilmu Kebidanan. Jakarta: Yayasan Bina Pustaka Sarwono

Shodiqoh, E. R., \& Syahrul, F. (2014). Perbedaan Tingkat Kecemasan dalam Menghadapi Persalinan antara Primigravida dan Multigravida. Jurnal Berkala Epidemiologi. 2 (1), 141-150. Diterima dari http://www.jounal.unair.ac.id/downloadfull/JBE8534-d73df33709fullabstr act.pdf. Pada tanggal 12 April 2019.

Stuart dan Sundeen. 2013. Keperawatan Jiwa Edisi 6. Jakarta: EGC. 19 Maret 2019.

Suliswati. (2014). Konsep Dasar Keperawatan Kesehatan Jiwa. EGC. Jakarta. 19 Maret 2019.

Supriyantini. (2010). Perbedaan Kecemasan Dalam Menghadapi Ujian Antar Siswa Program Reguler Dengan Program Akselerasi. Tesis. Universitas Sumatra Utara. Sumatra Utara. 19 Maret 2019.

Taluta, Y. P., Mulyadi \& Hamel, R. S., 2014. Hubungan Tingkat Kecemasan Dengan Mekanisme Koping pada Penderita Diabetes MelitusTipe 2 Di Poliklinik Peyakit Dalam Rumah Sakit Umum Daerah Tobelo Kabupaten Halmahera 
Utara. Ejourna keperawatan, 1 (2), pp. Wahyu Widosari, Yuke. 2010. Perbedaan $1-9$.

Derajat Kecemasan dan Depresi

https://ejournal.unsrat.ac.id/index.php/jk p/article/view/4059/3575. Tanggal 20

Mahasiswa Kedokteran Preklinik dan Maret 2019.

Ko-Asisten di FK UNS Surakarta.

Fakultas Kedokteran Universitas Sebelas

Maret Surakarta. Skripsi. 12 April 2019.

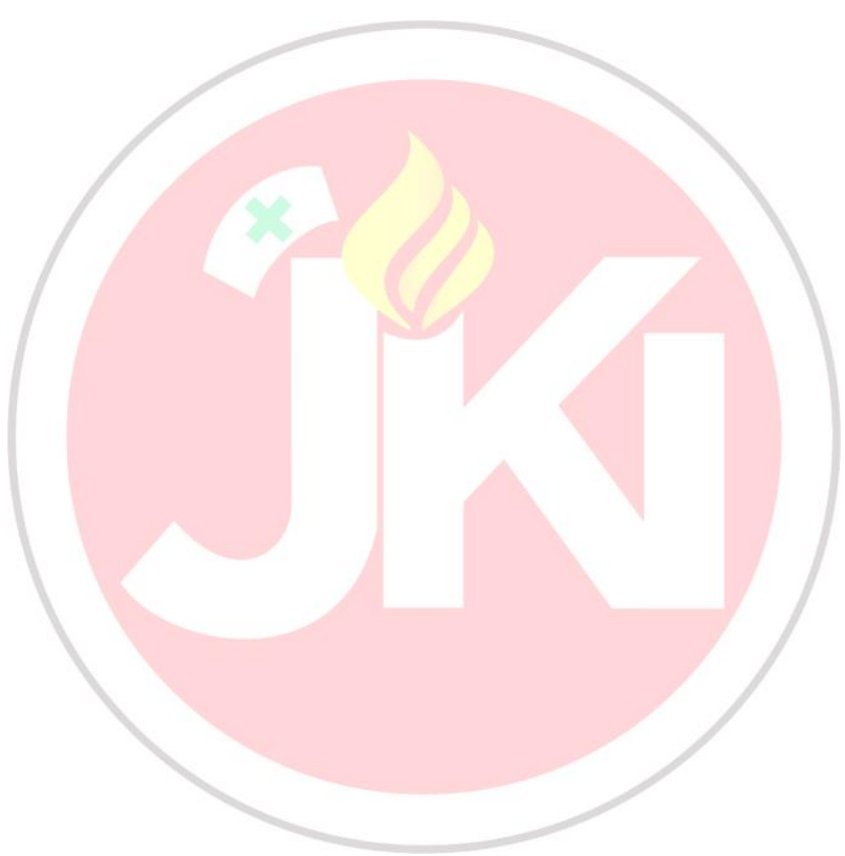

